\title{
Effects of lipopolysaccharide on low- and high-density cultured rabbit vascular smooth muscle cells: differential modulation of nitric oxide release, ERK1/ERK2 MAP kinase activity, protein tyrosine phosphatase activity, and DNA synthesis
}

L.C. Barbosa de O liveira ${ }^{1}$, C.J. Rocha O liveira1,2, D.M. Fries ${ }^{1}$, A. Stern ${ }^{3}$ and H.P. Monteiro ${ }^{1}$
${ }^{1}$ Fundação Pró-Sangue Hemocentro de São Paulo, São Paulo, SP, Brasil ${ }^{2}$ Disciplina de Biologia Molecular, Escola Paulista de Medicina, Universidade Federal de São Paulo, São Paulo, SP, Brasil ${ }^{3}$ Department of Pharmacology, New York U niversity Medical Center, New York, NY, USA

\section{Correspondence \\ H.P. Monteiro \\ Departamento de Bioquímica \\ Fundação Pró-Sangue \\ Hemocentro de São Paulo \\ Av. Enéas C. Aguiar, 155, 10 andar \\ 05403-000 São Paulo, SP \\ Brasil \\ Fax: + 55-11-853-2290 \\ E-mail: hpmonte@uol.com.br}

Research supported by FAPESP (No. 96/7927-5), PRONEX/CNPq (N o. 569 to H.P. Monteiro), and the National Institute of Environmental Health Sciences (No. ES03425 to A. Stern).

L.C. Barbosa de O liveira was a research fellow of $\mathrm{CNPq}$.

Received November 21, 2000 Accepted November 28, 2001

\section{Abstract}

Previous studies have shown that exogenously generated nitric oxide (NO) inhibits smooth muscle cell proliferation. In the present study, we stimulated rabbit vascular smooth muscle cells (RVSMC) with $E$. coli lipopolysaccharide (LPS), a known inducer of NO synthase transcription, and established a connection between endogenous NO, phosphorylation/dephosphorylation-mediated signaling pathways, and DNA synthesis. Non-confluent RVSMC were cultured with 0, 5, 10, or $100 \mathrm{ng} / \mathrm{ml}$ of the endotoxin. NO release was increased by $86.6 \%$ (maximum effect) in low-density cell cultures stimulated with $10 \mathrm{ng} /$ $\mathrm{ml}$ LPS as compared to non-stimulated controls. Conversely, LPS (5 to $100 \mathrm{ng} / \mathrm{ml}$ ) did not lead to enhanced NO production in multilayered (high density) RVSMC. DNA synthesis measured by thymidine incorporation showed that LPS was mitogenic only to non-confluent RVSMC; furthermore, the effect was prevented statistically by aminoguanidine (AG), a potent inhibitor of the inducible NO synthase, and oxyhemoglobin, an NO scavenger. Finally, there was a cell densitydependent LPS effect on protein tyrosine phosphatase (PTP) and ERK1/ERK2 mitogen-activated protein (MAP) kinase activities. Shortterm transient stimulation of ERK1/ERK2 MAP kinases was maximal at $12 \mathrm{~min}$ in non-confluent RVSMC and was prevented by preincubation with AG, whereas PTP activities were inhibited in these cells after 24-h LPS stimulation. Conversely, no significant LPS-mediated changes in kinase or phosphatase activities were observed in highdensity cells. LPS-induced NO generation by RVSMC may switch on a cell density-dependent proliferative signaling cascade, which involves the participation of PTP and the ERK1/ERK2 MAP kinases.
Key words

- Nitric oxide

- Lipopolysaccharide

- Protein tyrosine

phosphatases

- Mitogen-activated

protein kinases

- DNA synthesis

- Cell density 


\section{Introduction}

During embryonic life and in the young evolving organism, vascular smooth muscle cells (VSMC) actively divide, secrete extracellular matrix components and have a fibroblast-like appearance. In the adult, smooth muscle cells of the arterial media become highly specialized and non-secretory, acquiring a contractile phenotype and typically remaining at rest (reviewed in 1). A shift from contractile to proliferating VSMC is found during arterial wound healing and in several cardiovascular diseases $(2,3)$. This modulation of VSMC function has been observed not only in vivo but also in cell cultures (1). Among the factors influencing this process are the action of exogenous and/or endogenous nitric oxide (NO) (4-6), and cell density-dependent interactions $(7,8)$. NO is a gaseous free radical produced during the conversion of L-arginine to L-citrulline by constitutively expressed and inducible isoforms of the enzyme NO synthase. The constitutive isoform is present in endothelial cells and cerebellar neurons and is dependent on $\mathrm{Ca}^{2+} /$ calmodulin. Cytokines and the endotoxin lipopolysaccharide (LPS) from Escherichia coli promote the transcription of the inducible isoform of NO synthase in macrophages and smooth muscle cells (9). NO can function in cell signaling associated with smooth muscle cell relaxation and proliferation $(4-6,10,11)$. It reacts with the iron heme moiety of the soluble form of guanylyl cyclase or with critical thiols in protein kinases, protein phosphatases, and small $\mathrm{G}$ proteins $(12,13)$. Furthermore, recent reports have described a role for $\mathrm{NO}$ as a mediator/ modulator of protein tyrosine phosphorylation (14-16).

Proliferating cells normally display an increase in intracellular phosphotyrosine levels (reviewed in 17). Increased production of $\mathrm{NO}$ is found in actively dividing cell populations whenever NO has a positive role in cell growth $(18,19)$. Enhanced total protein ty- rosine phosphatase (PTP) activity has been reported in cells harvested at high densities (20). Oxidant inactivation of PTP in neutrophils and mast cells caused activation of ERK1/ERK2, members of the mitogen-activated protein kinase (MAP kinase) family $(21,22)$ that are typically involved in the control of cell cycle progression (23). Specifically, exogenously generated NO was shown to inhibit total PTP activity and also to stimulate ERK1/ERK2 activity in murine fibroblasts and rat mesangial cells (14-16).

Therefore, we investigated whether or not rabbit VSMC (RVSMC) cultured at two cell densities (high-density or multilayered cell cultures, and low-density or non-confluent cell cultures) and stimulated with LPS would produce endogenous NO differentially. We also compared the LPS-induced cell density-dependent NO production with the RVSMC patterns of DNA synthesis, total PTP activity and ERK1/ERK2 MAP kinase activity.

\section{Material and Methods}

\section{Material}

Cell culture reagents and tissue culture Petri dishes were from Gibco/BRL (Gaithersburg, MD, USA). Protein A-Sepharose CL4B, electrophoresis reagents, LPS (E. coli, tissue culture tested), PDGFbb, sulfanilamide, naphthylethylenediamine dihydrochloride, $\mathrm{H}_{3} \mathrm{PO}_{4}$, aminoguanidine (AG), phenylmethanesulfonyl fluoride (PMSF), pnitrophenol phosphate, and phenylarsine oxide were obtained from Sigma (St. Louis, MO, USA). Monoclonal antibody (mAb) 108.1 against the human epidermal growth factor (EGF) receptor was kindly provided by Dr. Yuri Ivaschenko (Rorer RhonePoulenc Biotechnology, King of Prussia, PA, USA). Monoclonal antibodies anti-p44/p42 ERK1/ERK2 MAP kinase and anti-phosphop44/p42 ERK1/ERK2 MAP kinase were purchased from New England Biolabs (Bev- 
erly, MA, USA). Oxyhemoglobin (Hb) was obtained from hemolysates of freshly drawn human blood donated by healthy volunteers. Briefly, erythrocytes obtained from $20 \mathrm{ml}$ of blood by centrifugation were washed twice with PBS, pH 7.4, and lysed with an equal volume of ultrapure deionized cold water. The hemolysate was centrifuged, and the supernatant collected and eluted through a Sephadex G-50 column equilibrated with 20 mM HEPES buffer, $\mathrm{pH}$ 7.5. The Hb concentration of the eluate was determined by reading the absorbance at $577 \mathrm{~nm}\left(\varepsilon_{577}=15,300\right.$ $\mathrm{M}^{-1} \mathrm{~cm}^{-1}$ ) (24). $\left[{ }^{3} \mathrm{H}\right]$-Thymidine (specific activity: $92 \mathrm{Ci} / \mathrm{mmol}$ ) was from Amersham Pharmacia Biotech (Little Chalfont, Buckinghamshire, UK).

\section{Determination of nitrite concentrations in culture supernatants}

The concentration of nitrite in cell-free supernatant was determined using Griess reagent ( $1 \%$ sulfanilamide, $0.1 \%$ naphthylethylenediamine dihydrochloride and $2 \%$ $\mathrm{H}_{3} \mathrm{PO}_{4}$ ). Briefly, $300 \mu \mathrm{l}$ culture supernatant was mixed with $300 \mu \mathrm{l}$ Griess reagent and incubated in an Eppendorf tube protected from light for $15 \mathrm{~min}$ at room temperature. Nitrite concentration was determined with a spectrophotometer with reference to $\mathrm{NaNO}_{2}$ as standard.

\section{Cell culture and treatments}

RVSMC from aorta were kindly donated by Dr. V. Buonassisi (INFAR, Escola Paulista de Medicina, São Paulo, SP, Brazil) (25). Cell cultures were maintained on F-12 medium supplemented with $10 \%$ FBS. Cells in multilayers were obtained by seeding 1.4 x $10^{4}$ cells $/ \mathrm{cm}^{2}$ in $56-\mathrm{cm}^{2}$ cell culture Petri dishes and incubating for $96 \mathrm{~h}$, with addition of fresh medium after $48 \mathrm{~h}$. Cells at low density were obtained by seeding $0.35 \times 10^{4}$ cells $/ \mathrm{cm}^{2}$ in $56-\mathrm{cm}^{2}$ cell culture Petri dishes and incubating for $24 \mathrm{~h}$. The cultures were kept at $37^{\circ} \mathrm{C}$ in an atmosphere of $5 \% \mathrm{CO}_{2}$ in air and incubated with serum-free medium for $24 \mathrm{~h}$ before treatments. Addition of LPS at different concentrations was carried out in F-12 medium containing $5 \mathrm{mM}$ HEPES, 1 $\mathrm{mM} \mathrm{Ca}{ }^{2+}$ and $0.1 \%$ FBS. Cells were then stimulated for 3, 6, 24 and $48 \mathrm{~h}$, and $90-95 \%$ cell viability (Trypan blue exclusion) was observed after the different times of incubation. When appropriate, $\mathrm{AG}(400 \mu \mathrm{M})$ or $\mathrm{Hb}$ $(20 \mu \mathrm{M})$ was added to the cell cultures 30 min prior to LPS induction, using cultures not stimulated with the endotoxin as controls. Culture supernatants or cell lysates were obtained by running the experiments in $56-\mathrm{cm}^{2}$ Petri dishes using a final volume of $4 \mathrm{ml}$ stimulation medium.

\section{Measurement of DNA synthesis}

RVSMC cultured in 96-well plates at the desired cell densities were stimulated as appropriate. Four hours prior to termination of the assay, $0.5 \mu \mathrm{Ci}$ of $\left[{ }^{3} \mathrm{H}\right]$-thymidine was added to each well. After a total stimulation period of $24 \mathrm{~h}$, trypsin was added to the cultures, which were incubated for a further $15 \mathrm{~min}$ at $37^{\circ} \mathrm{C}$. The cell suspensions were then collected into fiberglass filters using a cell harvester (LKB-Wallac model 1295201). After drying, the radioactivity incorporated into the material associated with the filters was measured with a Wallac 1205 Betaplate scintillation counter.

\section{Immunoprecipitation of the EGF receptor}

HER 14 cells (NIH 3T3 murine fibroblasts permanently transfected and overexpressing the human EGF receptor) (26), grown in Dulbecco's modified Eagle's medium supplemented with $10 \%$ FBS in 75$\mathrm{cm}^{2}$ flasks, were used as a source of human EGF receptor. The cells were solubilized in lysis buffer A (20 mM HEPES, pH 7.5, 150 $\mathrm{mM} \mathrm{NaCl}, 10 \%$ glycerol, $1 \%$ Triton X-100, $1.5 \mathrm{mM} \mathrm{MgCl}_{2}, 1 \mathrm{mM}$ EGTA, $1 \mu \mathrm{g} / \mathrm{ml}$ 
aprotinin, $1 \mu \mathrm{g} / \mathrm{ml}$ leupeptin, and $1 \mathrm{mM}$ PMSF) for $30 \mathrm{~min}$ on ice, and the insoluble material was removed by centrifugation. Preclearing was done by gently rotating lysates with added protein A-Sepharose for $1 \mathrm{~h}$ at $4^{\circ} \mathrm{C}$, followed by removal of protein A-Sepharose by centrifugation. Pre-cleared lysates were immunoprecipitated with mAb 108.1 against the human EGF receptor conjugated with protein A-Sepharose (27).

\section{Phosphorylation of the EGF receptor in vitro}

After washing the immunoprecipitated receptors with kinase buffer (20 mM HEPES, $\mathrm{pH}$ 7.5, $5 \mathrm{mM} \mathrm{MnCl}_{2}$, and $2 \mathrm{mM} \mathrm{MgCl} 2$ ), 8 $\mu \mathrm{Ci}$ of $\left[\gamma_{-}{ }^{32} \mathrm{P}\right]$-ATP was added to the immunoprecipitates and the mixture was incubated for $5 \mathrm{~min}$ at $25^{\circ} \mathrm{C}$. The reaction was stopped by the addition of HNTG buffer (20 mM HEPES, pH 7.5, $150 \mathrm{mM} \mathrm{NaCl}, 10 \%$ glycerol, $0.1 \%$ Triton $\mathrm{X}-100$ ) followed by three washes in this buffer. The labeled immunoprecipitate was resuspended in the same buffer and kept at $4^{\circ} \mathrm{C}$ for further use.

\section{PTP activity assay}

Treated or untreated RVSMC were lysed in buffer A. After $30 \mathrm{~min}$ on ice the lysates were centrifuged $\left(10 \mathrm{~min}, 11,750 \mathrm{~g}, 4^{\circ} \mathrm{C}\right)$ and the supernatants were used as the source of PTP activity. PTP activity was assayed by mixing $100 \mu \mathrm{g}$ protein from lysates with a suspension containing immunoprecipitated [ $\left.{ }^{32} \mathrm{P}\right]$-labeled EGF receptors, prepared essentially as described by Monteiro et al. (27). Reactions were carried out for $30 \mathrm{~min}$ at $37^{\circ} \mathrm{C}$ with shaking and terminated by centrifugation $(11,750 \mathrm{~g}$ for $1 \mathrm{~min})$ of the immunoprecipitates. Samples were resolved by SDS-PAGE (7.5\% gels) and, after drying, gels were exposed to autoradiographic films. The intensity of the band corresponding to the EGF receptor was determined by enhanced laser densitometry. The PTP activity index was determined according to the ex- pression: $1-\mathrm{x} / \mathrm{R}$, where $\mathrm{x}$ corresponds to the band intensity of the labeled immunoprecipitated EGF receptor incubated with cell lysates and $\mathrm{R}$ corresponds to the band intensity of the receptor in the absence of lysate.

\section{Western blot analysis of the ERK1/ERK2 MAP kinase activities}

Experimental evidence for LPS-stimulated ERK1/ERK2 activities was obtained by immunoblot analysis using specific antiphospho-ERK1/ERK2 antibodies. Cells were lysed in $250 \mu \mathrm{l}$ of lysis buffer A containing phosphatase inhibitors $(2 \mathrm{mM}$ sodium orthovanadate, $50 \mathrm{mM}$ sodium fluoride, and 10 $\mathrm{mM}$ sodium pyrophosphate). Total cell lysates $(50 \mu \mathrm{g} / \mathrm{lane})$ were resolved on $10 \%$ SDS-polyacrylamide gels. Gels were blotted onto nitrocellulose sheets, and blots were probed using $m A b$ againstERK1/ERK2 MAP kinase and phospho-ERK1/ERK2 MAP kinase. After incubation with an appropriate horseradish peroxidase-conjugated secondary antibody, blots were developed using the ECL system (Amersham Pharmacia Biotech).

\section{Statistical analysis}

Results are reported as means \pm SD. The Student $t$-test was used for statistical analysis, with the levels of significance set at $\mathrm{P}<0.01$ and $\mathrm{P}<0.05$.

\section{Results}

The time course of NO release by nonconfluent, low-density RVSMC exposed to LPS (10 ng/ml) indicated that nitrite concentrations in culture supernatants of stimulated cells were significantly $(\mathrm{P}<0.05)$ higher than control levels at $24 \mathrm{~h}$ (Figure 1A). The slight reduction in baseline nitrite concentrations at $48 \mathrm{~h}$ compared with 6 and $24 \mathrm{~h}$ is most likely due to the fact that the assay chosen to monitor NO production only measures released nitrite and does not take into account 
the predictable partial oxidation to nitrate over time (28). The RVSMC 24-h response was dose-dependent, maximal at $10 \mathrm{ng} / \mathrm{ml}$ (Figure 1B) and significantly $(\mathrm{P}<0.05)$ inhibited by $A G(400 \mu \mathrm{M})$, a potent inhibitor of inducible NO synthase (29) added to the cultures 30 min prior to introduction of the endotoxin (Figure 1C). By contrast, supernatant nitrite levels of multilayered RVSMC stimulated with either $10 \mathrm{ng} / \mathrm{ml}$ or $100 \mathrm{ng} / \mathrm{ml}$ LPS were closely similar to those of control cultures over a 24-h period (Figure 1D). Multilayered RVSMC stimulated with these same concentrations for $48 \mathrm{~h}$ also failed to produce significant NO above control levels (data not shown).

The patterns of DNA synthesis of nonconfluent and multilayered RVSMC elicited by LPS correlated positively with their density-dependent profiles of endogenous NO production. Dose-response curves showed an optimal incorporation of $\left[{ }^{3} \mathrm{H}\right]$-thymidine by low-density RVSMC at $10 \mathrm{ng} / \mathrm{ml} \mathrm{LPS}$ and $24 \mathrm{~h}$. Incorporation levels were comparable to positive control cultures stimulated with the platelet-derived growth factor bb (PDGFbb) (Figure 2A). Conversely, no incorporation of $\left[{ }^{3} \mathrm{H}\right]$-thymidine over control levels was observed in high-density RVSMC cultured with different doses of LPS over a 48-h period (Figure $2 B$ ). Increasing ten-fold the percentage of FBS in the medium of stimulated and non-stimulated high-density cultures did not alter their pattern of DNA synthesis (data not shown).

The proliferative response of low-density RVSMC was inhibited by $85-90 \%$ in the presence of $400 \mu \mathrm{M}$ AG (Figure 2C). The addition of $20 \mu \mathrm{M} \mathrm{Hb}$, an extracellular scavenger of NO (30), mitigated the pro-mitogenic effect of endogenous $\mathrm{NO}$, evidenced by inhibition of $\left[{ }^{3} \mathrm{H}\right]$-thymidine incorporation by about $65 \%$ (Figure 2C).

The 24-h mitogenic response of endotoxin-stimulated low-density RVSMC was accompanied by a significant $(\mathrm{P}<0.01) 24-\mathrm{h}$ inhibition of PTP activity in cell lysates with
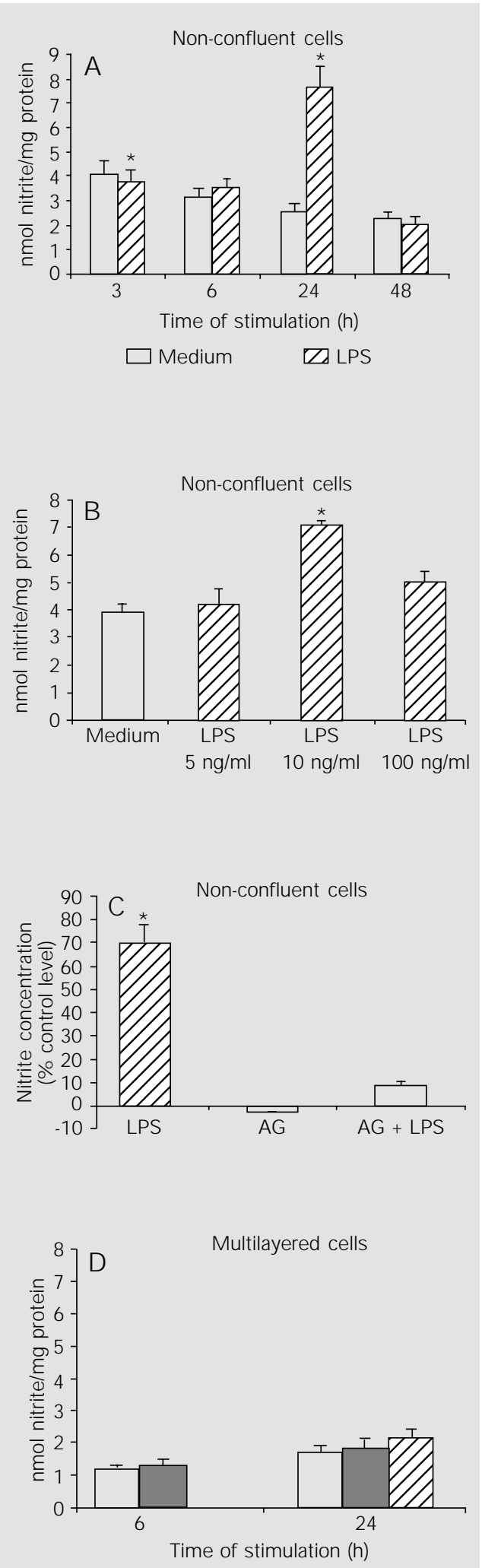

Medium $\square$ LPS $10 \mathrm{ng} / \mathrm{ml} \quad \square$ LPS $100 \mathrm{ng} / \mathrm{ml}$
Figure 1. Lipopolysaccharide (LPS)-stimulated NO release by rabbit vascular smooth muscle cells (RVSMC). RVSMC were serum-starved for $24 \mathrm{~h}$ before incubation with LPS. A, Nonconfluent, low-density RVSMC were exposed to LPS $(10 \mathrm{ng} / \mathrm{ml})$ or medium at the times indicated. $* \mathrm{P}<0.05$ compared to medium at the same time (Student t-test). B, Non-confluent, low-density RVSMC were exposed to LPS at the indicated concentrations for $24 \mathrm{~h} . * \mathrm{P}<0.05$ compared to medium and other concentrations of LPS (Student t-test). C, Non-confluent, lowdensity RVSMC were exposed to aminoguanidine (AG, $400 \mu \mathrm{M}$ ) 30 min prior to 24 -h stimulation with LPS $(10 \mathrm{ng} / \mathrm{ml}) . * P<0.05$ compared to cells pretreated with AG and stimulated or not with LPS (Student t-test). D, Multilayered RVSMC were incubated for $24 \mathrm{~h}$ with LPS at two different concentrations (10 and $100 \mathrm{ng} / \mathrm{ml}$ ). After incubation, NO production was estimated as accumulated nitrite in cell culture supernatants. Results are reported as means \pm SD of three independent experiments performed in quadruplicate. 

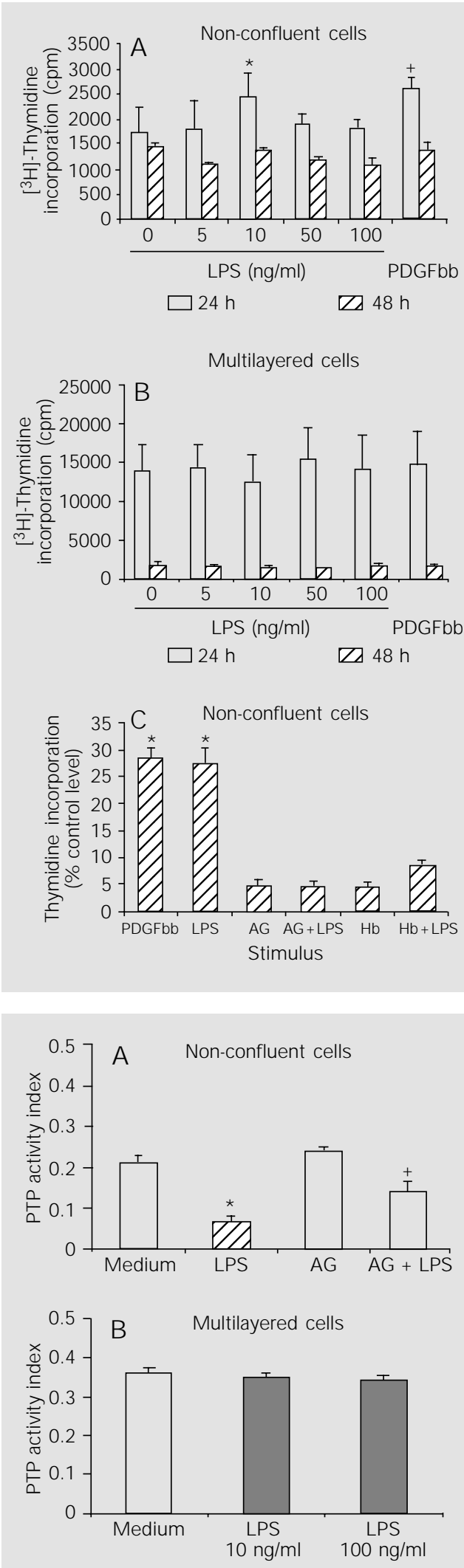

Figure 2. Effect of lipopolysaccharide (LPS)-induced endogenous NO production on rabbit vascular smooth muscle cell (RVSMC) DNA synthesis. Non-confluent, low-density RVSMC (A) and multilayered cultures (B) were incubated with the indicated concentrations of LPS for 20 and $44 \mathrm{~h}$. Positive control cultures were incubated with platelet-derived growth factor bb (PDGFbb, $10 \mathrm{ng} / \mathrm{ml}$ ) for the same period of time. C, Non-confluent, low-density RVSMC were preincubated with aminoguanidine $(A G, 400 \mu \mathrm{M})$ or hemoglobin $(\mathrm{Hb}$, $20 \mu \mathrm{M}$ ) as indicated, and then stimulated with LPS (10 $\mathrm{ng} / \mathrm{ml}$ ) for 20 and $44 \mathrm{~h}$. Cells were then pulse labeled with $\left[{ }^{3} \mathrm{H}\right]$-thymidine $(0.5 \mu \mathrm{Ci})$ for an additional period of $4 \mathrm{~h}$ (total time of incubation $=24$ and $48 \mathrm{~h}$ ). Cells were harvested and the radioactivity incorporated was determined as described in Material and Methods. Data are reported as incorporated $\mathrm{cpm}$ of $\left[{ }^{3} \mathrm{H}\right]$-thymidine $(\mathrm{A}$ and $B)$. In $\mathrm{C}$ data are reported as percentage of $\left[{ }^{3} \mathrm{H}\right]$-thymidine incorporation over control (non-stimulated) levels $\pm \mathrm{SD}(\mathrm{N}=4$; assay performed in 10 replicates). A, *P $<0.05$ compared to cells treated with other concentrations of LPS at $24 \mathrm{~h}$ and with all concentrations of LPS at $48 \mathrm{~h} ;+\mathrm{P}<0.05$ compared to all concentrations of LPS at $24 \mathrm{~h}$ except for $10 \mathrm{ng} / \mathrm{ml}$ (Student t-test). C, $* \mathrm{P}<0.05$ compared to cells preincubated with other stimuli (Student t-test).

Figure 3. Effects of lipopolysaccharide (LPS)-induced NO production on protein tyrosine phosphatase (PTP) activities in rabbit vascular smooth muscle cells (RVSMC). RVSMC were incubated for $24 \mathrm{~h}$ with LPS. A, Non-confluent, low-density RVSMC were exposed to LPS $(10 \mathrm{ng} / \mathrm{ml})$. The inducible NO synthase inhibitor aminoguanidine (AG, $400 \mu \mathrm{M}$ ) was added 30 min prior to the incubation with the endotoxin, as indicated. B, Concentration-dependent effects of LPS on RVSMCassociated PTP activities in multilayered cultures. After $24 \mathrm{~h}$, cells were lysed and lysates had their protein concentration determined. Protein contents were matched $(100 \mu \mathrm{g})$ and PTP activity in lysates was measured as described in Material and Methods. Results are reported as means $\pm S D$ of three independent experiments. $* \mathrm{P}<0.01$ compared to medium and $+\mathrm{P}<0.05$ compared to cells pretreated with AG (Student t-test). 
respect to control levels. A partial recovery of total PTP activity was obtained when 24-h low-density cell cultures were treated with AG (Figure 3A). Conversely, high-density RVSMC cultures stimulated either with $10 \mathrm{ng} /$ $\mathrm{ml}$ or $100 \mathrm{ng} / \mathrm{ml}$ LPS showed PTP activity levels similar to those of non-stimulated cells. Noteworthy, PTP activities were two-fold higher in non-stimulated and LPS-stimulated high-density cultures as compared to nonstimulated low-density cultures (Figure 3B).

Changes with time in the activity of the ERK1/ERK2 MAP kinases were observed in low-density RVSMC cultures stimulated with $10 \mathrm{ng} / \mathrm{ml}$ LPS. Maximum activation occurred at 12-min stimulation. Preincubation of the cells with $400 \mu \mathrm{M}$ AG prevented the LPSstimulated activation of ERK1/ERK2 MAP kinases, suggesting the participation of $\mathrm{NO}$ in the process (Figure 4A). By contrast, multilayered RVSMC showed no changes in ERK1/ERK2 MAP kinase activities in response to the incubation with LPS at 5-, 12-, 30-, and 60-min stimulation (Figure 4B).

\section{Discussion}

Low-density RVSMC, as opposed to highdensity cells, were stimulated to release NO following 24-h incubation with $10 \mathrm{ng} / \mathrm{ml}$ LPS. This NO response was strongly inhibited by AG, a potent and selective inhibitor of inducible NO synthase (29). It was previously documented that at $400 \mu \mathrm{M}$, the concentration used in our study, AG causes over $90 \%$ inhibition of inducible NO synthaseelicited cGMP production by VSMC, with no inhibition of constitutive NO synthase activity (29). This suggests that the differential NO response of low-density RVSMC to LPS was dependent on inducible NO synthase activity. The data presented indicate a density-dependent mitogenic response of RVSMC to LPS, which is mediated by NO. Various cell types are known to undergo NO-induced arrest of cell division $(4,31,32)$. Studies on the interaction between VSMC and vascular NO (33) or NO released from NO donors (4-6) have demonstrated that this gaseous free radical has an antimitotic ef-
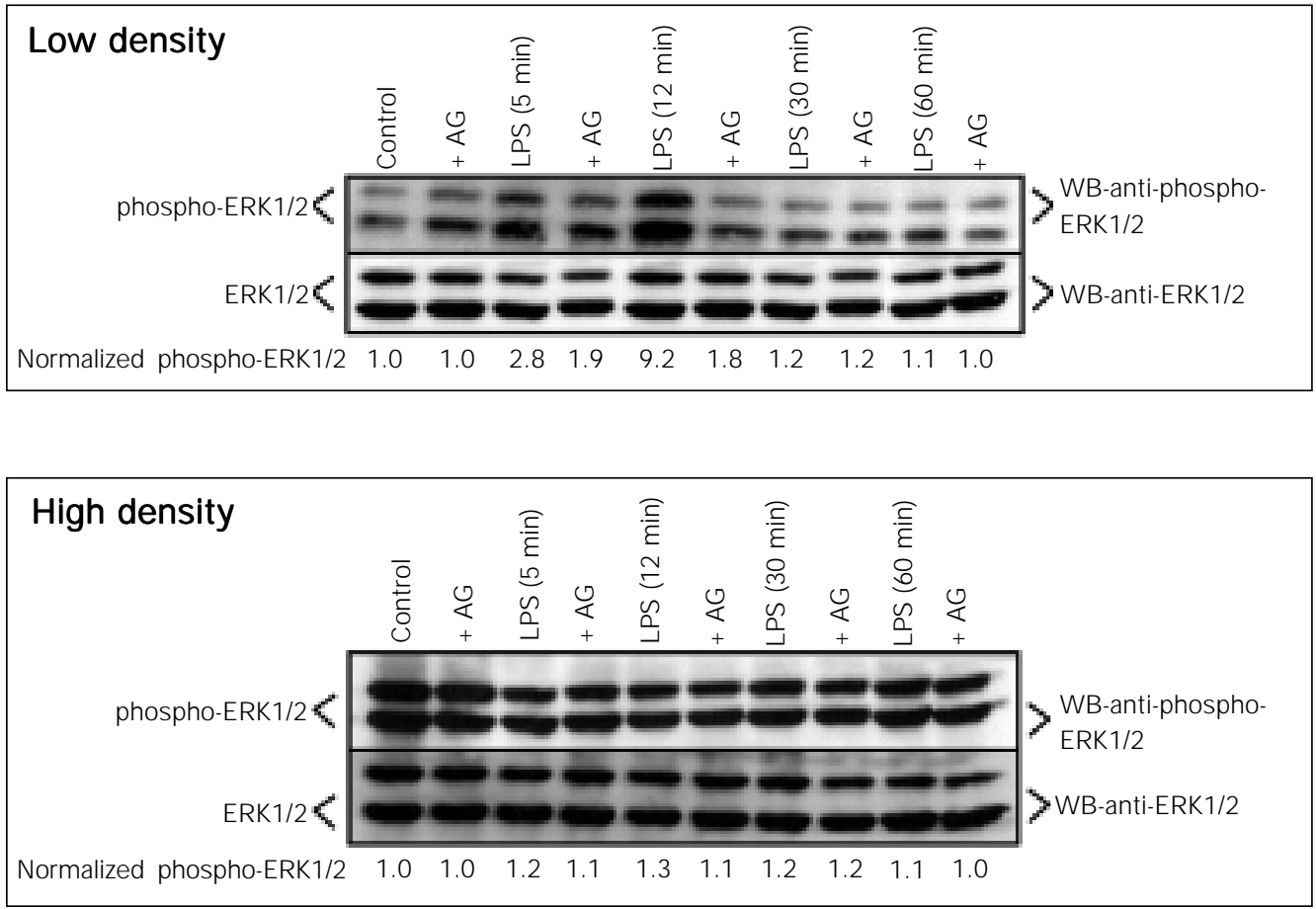

Figure 4. Time-dependent lipopolysaccharide (LPS) stimulation of rabbit vascular smooth muscle cells (RVSMC) for ERK1/ ERK2 activities. Low-density, non-confluent RVSMC (A) and multilayered cultures (B) were stimulated with LPS for the indicated periods of time and ERK1/ ERK2 activities were estimated using anti-phospho-ERK1/2 and anti-ERK1/2 antibodies as described in Material and Methods. Representative Western blots (WB) of both situations are shown. $A G=$ aminoguanidine. 
fect, although a cell density-dependent stimulation of NO synthase activity was not specifically addressed. On the other hand, both in vivo and in vitro data support a positive role for NO during cell growth. The NO donor sodium nitroprusside was found to potentiate substance $\mathrm{P}$ and $\mathrm{PGE}_{1}$-induced neovascularization in rabbits, while NO synthase inhibitors abolished endothelial cell proliferation in the same animal model (18). A human colonic adenocarcinoma cell line stably transfected with inducible NO synthase cDNA and presenting sustained release of NO consistently grew faster as a xenograft in nude mice when compared with the wild type and/or transfection controls, and promoted angiogenic activity (34). Furthermore, a positive correlation between cell proliferation, lower state of confluence and induction of NO synthase mRNA was reported by Arnal et al. (35) for endothelial cell cultures. In agreement with these studies, our data on non-confluent LPS-stimulated RVSMC showed significant stimulation of DNA synthesis, which was dependent upon increased production of NO. Interestingly, the inhibition of LPS-stimulated thymidine incorporation by $\mathrm{AG}$ and $\mathrm{Hb}$ reported herein suggests that inducible NO synthasegenerated NO not only acted in an autocrine manner but may also have had a paracrine effect on proliferating low-density RVSMC.

It has been argued that NO-mediated proliferation might involve lower concentrations of this free radical, whereas inhibition of proliferation would be associated with high concentrations of NO (34). Indeed, IL-1-induced lower NO levels did cause a transient $(24 \mathrm{~h})$ peak of DNA synthesis by bovine VSMC, which decreased as NO levels increased upon continuous stimulation (6). We showed that RVSMC at low density exhibited significant DNA synthesis after 24-h LPS (10 ng/ml) stimulation, accumulating approximately $7.6 \mu \mathrm{M}$ nitrite in culture supernatants. However, low-density RVSMC showed an average $40 \%$ drop in DNA syn- thesis after 24-h incubation with $1 \mathrm{mM}$ sodium nitroprusside, that generated $10 \mu \mathrm{M}$ nitrite (average) in cell-free medium (data not shown). This suggests that pro- and antiproliferative responses for the same state of cell confluence may depend on specific concentrations of available NO.

A reduced growth rate and $\left[{ }^{3} \mathrm{H}\right]$-thymidine incorporation reported for normal and transformed animal cells due to overexpression of a cytosolic low-molecular weight PTP (36) lend support to the relationship between PTP activity and mitogenesis. Multilayered RVSMC cultures feature a typical "hills and valleys" morphology (7), presenting basal PTP activities slightly greater than those of 24-h low-density control cultures. Such difference suggests modulation of PTP by cell-to-cell contact. In fact, an enhanced expression of receptor-like PTP with increasing cell density has been described in fibroblasts of different origins (37). PTP-mediated differences in DNA synthesis between low-density and confluent cell cultures stimulated with EGF and PDGF were recently described by Sörby and Östman (38). These authors demonstrated inhibition of thymidine incorporation at high cell density correlating with reduced tyrosine phosphorylation of the growth factor receptors.

All PTP feature a conserved cysteine residue in their catalytic domain, and reactions with NO and other oxidants render the enzyme catalytically inactive $(14,27)$. Therefore, it is reasonable to postulate that the inhibition of total PTP activity presently observed was due to enzyme inactivation by NO. Interestingly, the LPS-stimulated mitogenic response of low-density RVSMC appears to rely on inducible generation of NO and PTP activity. Increased PTP activity at high cell density may act as a restraint on NO generation by inhibiting tyrosine phosphorylation of inducible NO synthase, preventing an increase in enzyme activity (39) and hence precluding a significant mitogenic response. Cell contact, however, must affect 
other factors directly involved in the control of VSMC DNA synthesis and cell division (8).

Recently, we showed that ERK1/ERK2 are involved in NO signaling in 3T3 fibroblasts stably expressing the human EGF receptor (HER14 cells). Depletion of intracellular levels of glutathione preceded NO-dependent stimulation of ERK1/ERK2 (16). On the other hand, evidence from in vivo experimental models has shown that intracellular levels of glutathione decrease in association with LPS-stimulation of inducible NO synthase expression (40). Therefore, LPS-induced NO generation in VSMC may also decrease intracellular glutathione and promote the activation of ERK1/ERK2.

To conclude, we have shown that LPSinduced endogenous NO generation may switch on a cell density-dependent proliferative signaling cascade in RVSMC, which involves partial inactivation of PTP and activation of ERK1/ERK2 MAP kinases. The predominance of dividing or resting cells as a function of cell density might thus depend on the ability of these cell populations to produce NO. Intracellular levels of NO will regulate PTP activity and the activity of MAP kinases associated with cell division. Our data may have some bearing on pathological states like atherosclerosis, where, despite a putative antiatherogenic role for NO (2), smooth muscle cells of the media that recently migrated to the intima of the vessel wall may respond to inflammatory stimuli by endogenous NO-dependent proliferation, creating a center of cell growth.

\section{References}

1. Thyberg J, Hedin U, Sjolund M, Palmberg L \& Bottger BA (1990). Regulation of differentiated properties and proliferation of aortic smooth muscle cells. Arteriosclerosis, 10: 966-990.

2. Ross R (1993). The pathogenesis of atherosclerosis: a perspective for the 1990's. Nature, 362: 801-809.

3. Schwartz RS, Holmes DR \& Topol EJ (1992). The restenosis paradigm revisited: an altemative proposal for mechanisms. J ournal of the American College of Cardiology, 20: 1284-1293.

4. Garg UC \& Hassid A (1989). NO-generating vasodilators and 8-bromo CGMP inhibit mitogenesis and proliferation of cultured vascular smooth muscle cells. J ournal of Clinical Investigation, 83: 1774-1777.

5. Mooradian DL, Hutsell TC \& Keefer LK (1995). NO donor molecules: effect of NO release rate on vascular smooth muscle cell proliferation in vitro. J ournal of Cardiovascular Pharmacology, 25: 674-678.

6. Fukuo K, Inoue T, Morimoto S, Nakahashi T, Yasuda O, Kitano S, Sasada R \& Ogihara $T$ (1995). NO mediated cytotoxicity and bFGF release in cultured smooth muscle cells. J ournal of Clinical Investigation, 95: 669-676.

7. Chamley-Campbell J, Campbell GR \& Ross R (1979). The smooth muscle cells in culture. Physiological Reviews, 59: 161.
8. Sjölund M, Hedin U, Sejersen T, Heldin CH \& Thyberg J (1988). Arterial smooth muscle cells express PDGFa mRNA, secrete a PDGF-like mitogen and bind exogenous PDGF in a phenotype- and growth state-dependent manner. J ournal of Cell Biology, 106: 403-413.

9. Knowles RG \& Moncada S (1994). Nitric oxide synthases in mammals. Biochemical J oumal, 298: 249-258.

10. Kelm M, Feelisch M, Spahr R, Piper HM, Noack E \& Schrader J (1988). Quantitative and kinetic characterization of nitric oxide and EDRF released from cultured endothelial cells. Biochemical and Biophysical Research Communications, 154: 236-244.

11. Ignarro LJ (1989). Biological actions and properties of endothelium-derived nitric oxide formed and released from artery and vein. Circulation Research, 65: 1-21.

12. Gruetter D, Gruetter CA, Barry BK, Baricos WH, Hyman AL, Kadowitz PJ \& Ignarro LJ (1980). Activation of coronary arterial guanylate cyclase by nitric oxide, nitroprusside and nitrosoguanidine - inhibition by calcium, lanthanum, and other cations, enhancement by thiols. Biochemical Pharmacology, 29: 2943-2950.

13. Lander HM, Ogiste J S, Pearce SFA, Levi R \& Novogrodsky A (1995). Nitric oxidestimulated guanine nucleotide exchange on p21Ras. J ournal of Biological Chemistry, 270: 7017-7020.
14. Peranovich TMS, da Silva AM, Fries DM Stern A \& Monteiro HP (1995). Nitric oxide stimulates tyrosine phosphorylation in murine fibroblasts in the presence and absence of epidermal growth factor. Biochemical J ournal, 305: 613-619.

15. Callsen D, Sandau KB \& Brune B (1999). Nitric oxide and superoxide inhibit platelet-derived growth factor receptor phosphotyrosine phosphatases. Free Radical Biology and Medicine, 26: 1544-1553.

16. Monteiro HP, Gruia-Gray J, Peranovich TMS, Barbosa de Oliveira LC \& Stem A (2000). Nitric oxide stimulates tyrosine phosphorylation of focal adhesion kinase, Src kinase, and mitogen activated protein kinases in murine fibroblasts. Free Radical Biology and Medicine, 28: 174-182.

17. Schlessinger J \& Ullrich A (1992). Growth factor signaling by receptor tyrosine kinases. Neuron, 9: 383-391.

18. Ziche M, Morbidelli L, Masini E, Amerini S, Granger HJ , Maggi CA, Geppetti P \& Ledda $F$ (1994). NO mediates angiogenesis in vivo and endothelial cell growth and migration in vitro promoted by SP. J ournal of Clinical Investigation, 94: 20362044.

19. Ghigo $D$, Arese $M$, Todde $R$, Vecchi $A$, Silvagno $F$, Costamagna $C$, Dong QG, Alessio M, Heller R, Soldi R, Trucco F, Garbarino G, Pescarmona G, Mantovani A, Bussolino F \& Bosia A (1995). Middle 
T-antigen-transformed endothelial cells exhibit an increased activity of NO synthase. J ournal of Experimental Medicine, 181: 9-19.

20. Mansbridge J N, Knuchel R, Knapp AMM \& Sutherland RM (1992). Importance of tyrosine phosphatases in the effects of cell-cell contact and microenvironments on EGF-stimulated tyrosine phosphorylation. J oumal of Cellular Physiology, 151: 433-442.

21. Fialkow $L$, Chan $C K$, Rotin D, Grinstein $S$ \& Downey GP (1994). Activation of the mitogen-activated protein kinase signaling pathway in neutrophils. J ournal of Biological Chemistry, 269: 31234-31242.

22. Santini $F \&$ Beaven MA (1993). Tyrosine phosphorylation of a mitogen-activated protein kinase-like protein occurs at a late step in exocytosis. J oumal of Biological Chemistry, 268: 22716-22722.

23. Garrington TP \& J ohnson GL (1999). Organization and regulation of mitogen-activated protein kinase signaling pathways. Current Opinion in Cell Biology, 11: 211218.

24. Riggs A (1981). Preparation of blood hemoglobins of vertebrates. Methods in Enzymology, 76: 5-28.

25. Buonassisi V \& Colbum P (1980). Hormone and surface receptors in vascular endothelium. In: Altura BM (Editor), Advances in Microcirculation. S. Karger, Basel, Switzerland.

26. Honneger AM, Dull TJ, Felder S, Van Obberghen E, Bellot F, Szapary D, Schmidt A, Ullrich $A \&$ Schlessinger J (1987). Point mutation at the ATP binding site of EGF receptor abolishes proteintyrosine kinase activity and alters cellular routing. Cell, 51: 199-209.

27. Monteiro HP, Ivaschenko $\mathrm{Y}$, Fisher $\mathrm{R} \&$ \& Stern A (1991). Inhibition of protein tyrosine phosphatase activity by diamide is reversed by epidermal growth factor in fibroblasts. FEBS Letters, 295: 146-148.

28. Laurenti $M$, Lepoivre $M \&$ \& Tenut JP (1996). Kinetic modeling of the nitric oxide gradient generated in vitro by adherent cells expressing inducible nitric oxide synthase. Biochemical J oumal, 314: 109113.

29. Thomas PM, Moore WM, Kasten TP, Nickols GA, Corbett JA, Tilton RG, McDaniel ML, Williamson J R \& Currie MG (1993). Selective inhibition of the inducible nitric oxide synthase by aminoguanidine. European J ournal of Pharmacology, 233: 119-125.

30. Ignarro LJ , Buga GM, Wood KS, Byrns RE \& Chaudhuri G (1987). Endothelium-derived relaxing factor produced and released from artery and vein is nitric oxide. Proceedings of the National Academy of Sciences, USA, 84: 9265-9269.

31. Stemberg J \& McGuigan F (1992). NO mediates suppression of $\mathrm{T}$ cell responses in murine $\mathrm{T}$. brucei infection. European J ournal of Immunology, 22: 2741-2744.

32. Maciejewski J P, Carmine $S$, Tadatsugu $S$, Cho HJ , Keefeer LK \& Nathan CF (1995). NO suppression of human hematopoiesis in vitro. J ournal of Clinical Investigation, 96: 1085-1092.

33. Cooke J P \& Tsao PS (1994). Is NO an endogenous antiatherogenic molecule? Arteriosclerosis and Thrombosis, 14: 653655.

34. J enkins DC, Charles IG, Thomsen LL, Moss DW, Holmes LS, Baylis SA, Rhodes
P, Westmore K, Emson PC \& Moncada S (1995). Roles of NO in tumor growth. Proceedings of the National Academy of Sciences, USA, 92: 4392-4396.

35. Amal J F, Yamin J, Dockery $S \&$ Harrison DG (1994). Regulation of endothelial NO synthase mRNA, protein, and activity during cell growth. American J ournal of Physiology, 267: C1381-C1388.

36. Ruggiero M, Pazzagli C, Rigacci G, Berti A, Chianugi VP, Pierce JH, Camici G \& Ramponi G (1993). Negative growth control by a novel low $M(r)$ phosphotyrosine protein phosphatase in normal and transformed cells. FEBS Letters, 326: 294-298.

37. Östman A, Yang Q \& Tonks NK (1994). Expression of DEP-1, a receptor-like protein tyrosine-phosphatase, is enhanced with increasing cell density. Proceedings of the National Academy of Sciences, USA, 91: 9680-9684.

38. Sörby $M \&$ O Östman A (1996). Protein tyrosine phosphatase-mediated decrease of epidermal growth factor and platelet-derived growth factor receptor tyrosine phosphorylation in high cell density cultures. J ournal of Biological Chemistry, 271: 10963-10966.

39. Pan J, Burgher KL, Szczepanik AM \& Ringheim G (1996). Tyrosine phosphorylation of inducible nitric oxide synthase: implications for potential post-translational regulation. Biochemical J ournal, 314: 889-894.

40. Zhang C, Walker LM, Hinson J A \& Mayeux PR (2000). Oxidant stress in rat liver after lipopolysaccharide administration: effect of inducible nitric oxide synthase inhibition. J oumal of Pharmacology and Experimental Therapeutics, 293: 968-972. 